\title{
Morality and boundaries in Paul
}

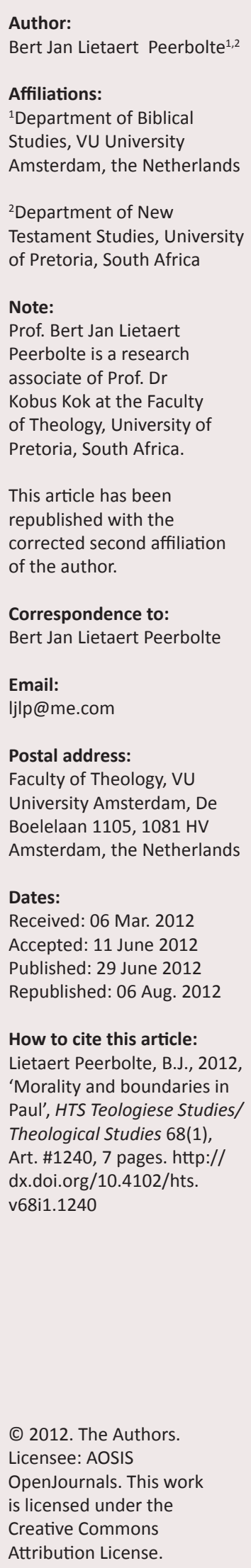

Author:

Bert Jan Lietaert Peerbolte ${ }^{1,2}$

Affiliations:

Department of Biblical

Studies, VU University

${ }^{2}$ Department of New

Testament Studies, University

ia, South Afric

associate of Prof. Dr

Kobus Kok at the Faculty

of Theology, University of

This article has been

republished with the corrected second affiliation

Correspondence to:

Bert Jan Lietaert Peerbolte

Email:

Postal address:

Faculty of Theology, VU

University Amsterdam, De

Boelelaan 1105, $1081 \mathrm{HV}$

Dates:

Received: 06 Mar. 2012

Accepted: 11 June 2012

Published: 29 June 2012

published: 06 Aug. 2012

'Morality and boundaries in

Paul', HTS Teologiese Studies/

dx.doi.org/10.4102/hts.

v68i1.1240
In the Pauline communities, ethics, ethos and identity were closely intertwined. This essay analyses the way in which Paul emphasised the mental boundaries of the Christ communities to turn them into moral boundaries. In this process, the fencing off of these communities over against their past and their present was a fundamental feature of Paul's reasoning. The communities thus became fenced off from their past, because the Christ event was seen as causing a major change in history. This change affected both Gentile and Jewish believers. At the same time, Paul stressed the boundaries with the outside world: he characterised the inside world as the loyal remnant of Israel, consisting of Jews and Gentiles alike, and pointed out that this group is the group of the elect 'saints'. The perspective with which Paul looked at ethics and morality inside this group was strongly coloured by the assumed identity of this group as 'Israel'. Even though the Mosaic Law was no longer the focal point for the identity of this eschatological Israel, the ethical demands Paul mentioned over against the members of this new Israel were highly influenced by the morality of the law. For Paul, sanctification was a fundamental ideal, and this ideal reflected the spirituality of the Holiness Code of Leviticus. This particular ethical model was framed by the awareness that Paul (and Christ before him) was 'sent' by God, much in the same way the prophets of Israel themselves had been sent.

\section{Preface}

One of the most fascinating elements about the religious movement that Paul started is its combination of continuity and discontinuity with its surrounding cultural and religious contexts. ${ }^{1}$ The more you look at Paul's ethical admonitions, the more significant the continuity with Hellenistic Judaism, but also with popular pagan ideas, becomes. ${ }^{2}$ Many authors have noticed this, but it is so important that it is worth the repetition: Paul's ethics do not significantly differ from the ideas we find in his context. His instructions for the household, his views of right and wrong, his stress on values such as autarkeia, enkrateia, and eusebeia - none of it is unique in his world. ${ }^{3}$ At the same time, however, it appears that life in the Christ communities Paul founded did differ significantly from what happened outside these groups. This means that a search for understanding the moral dynamics of Paul's religion is also a search for reconstructing the way in which his Christ groups defined their own identity over against the outside world. It is not by accident that Jan van der Watt's (2006) volume on the subject bears the title Identity, Ethics, and Ethos in the New Testament. The three nouns mentioned are indeed related, and for this reason, it seems best to focus this contribution on the dynamics of these three terms in Paul.

Much has been written and said on the topic of identity formation in Paul, and the importance of morality for identity formation is clearly stated by Wayne Meeks. He argues that morality is closely connected to the process of identity formation in the early Christ communities:

My thesis is that we cannot begin to understand the process of moral formation until we see that it is inextricable from the process by which distinctive communities were taking shape. Making morals means making community. (Meeks 1993:5)

Paul's 'ecclesiology' (if it is allowed to use this term in a totally anachronistic manner) defines the framework in which he takes an ethical stand. The main thesis of this essay is that Paul's

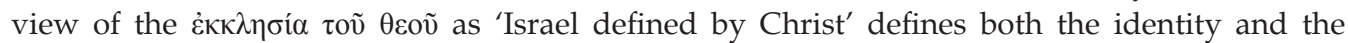
morality of the followers of Christ. Paul defines the identity of the Christ groups in terms of Israel, and subsequently uses the moral framework of the Torah as the structuring principle for the group's ethos. He does so by fencing off the Christ groups from the outside world as well as from the past, equates the Christ groups with Israel itself, and uses traditional Jewish values of 'holiness' and 'righteousness' in a new context. Where sanctification was a common ideal for 1.The present author has tried to emphasise this in his Dutch introduction to Paul: Lietaert Peerbolte (2010).

2.Here, the seminal work of Abraham Malherbe has ushered in a new wave of research on Paul and popular philosophical ideas. See especially Malherbe $(1986,1987$ \& 1989).

3.See also Lietaert Peerbolte (2003). 
Torah-obedient Jews, it also became the ideal for adherents of Jesus Christ. The exact way to lead a 'holy life', however, had to be reconstructed according to the different contexts in which people lived and behaved, and thus there is a certain contingency to Paul's moral admonitions. According to the line of reasoning presented in this contribution, the basic structure is clear: Paul was convinced that in Christ Israel had received its new form, and pagans were welcomed to Israel. This changed the status of the Torah, but did not change the ideals of righteousness and holiness. What sometimes is being regarded as 'Christian ethics' in Paul is nothing less than Jewish morality rephrased in a new, Christ-oriented context.

Before this thesis can be substantiated, a few things will have to be said about the words 'ethics', 'ethos', and 'morality'. The term 'mission' should also be discussed in more detail before it can be used in the rest of this contribution. This terminological discussion will be the main corpus of the first section (Introduction). After this, the focus will be on the ways in which Paul creates a mental boundary between present and past in his letters (Fencing off the Past). The ultimate example is of course 1 Thessalonians 1:9-10, where Paul presents his followers' break with the past as a 'turning away from the idols, toward the living God'. The next section (Fencing off the Present) treats the boundaries with the outside world: how does Paul rhetorically mark the distinction between those who are 'in Christ' and those who are not? After this (Nobless Oblige) Paul's ideals of righteousness and sanctification are discussed as ground structures for his view of morality. In the final section (Mission and the Narrative Substructure of Paul's Ideas), Paul's conception of mission will be analysed as an indication of the narrative substructure of his moral ideals. The last part of this article contains a summary and conclusion.

\section{Introduction}

\section{Ethics, morality, and identity in Paul}

One of the problems in dealing with Paul and early Christian literature in general is posed by the terms we use in our analysis. Numerous essays and books have been written in which this problem is addressed, so it is far from new. ${ }^{4}$ And yet, before we can start to analyse Paul's discourse with regard to the issues we are dealing with in this volume, the instruments with which to approach his writings will have to be defined.

It has become more or less customary to follow in Wayne Meeks' wake and to distinguish between ethics and ethos or morality (Meeks 1993:3-5). Meeks has argued that ethos or morality is concerned with the way in which people act in their everyday life, whereas ethics concerns the reflection of morality in a more theoretical framework: 'I take "ethics" in the sense of a reflective, second-order activity: it is morality rendered self-conscious' (Meeks 1993:4).

4.Two publications that focus strongly on this problem are Gager (2000) and Eisenbaum (2009)
Meeks' distinction has become popular, because it is recognisable. The present author is not an ethicist, does not specialise in ethics, but certainly hopes to have a certain ethos. Focusing on the latter, ethos, we are pressed to realise, that behaviour is always part of a group interaction. ${ }^{5}$ Hence, ethos or morality - some may distinguish between the two terms, but here they are used as synonyms - is directly related to social practice. For the present purpose, ethos may be defined as that type of behaviour that is considered morally acceptable both at an individual and at a group level. In this sense, remarks that depict a certain ethos refer to the type of in-group behaviour that an author wishes to stimulate by his writing.

The distinction between ethos or morality and ethics strongly resembles the tension between Paul's faith and his 'theology'. 6 Paul was a believer, a faithful servant of Jesus Christ - in his own terms - and he held certain strong beliefs about Christ, God, humankind, and the world. But only the reflection on those beliefs can possibly be called 'theology'.

It is here that the difficulties begin: can we assume that Paul held any views without some kind of reflection on them? Can we say that Paul's faith was totally unreflective, and not influenced by any kind of theology? Can we say that there was anything like 'ethos', an accepted set of actions, without any kind of reflection ('ethics') about them? Putting the question this way, is actually answering it. It is impossible to separate the two (ethos and ethics) completely, and for that reason it is important to notice that the difference between ethics on the one hand and ethos or morality on the other hand is primarily a heuristic distinction. Neither morality nor faith ever exists without any kind of reflection. At the same time, ethics are usually connected to some kind of practice, just as theology is connected to faith.

Given the need to be clear with regard to the terms used to analyse Paul, the idea of 'identity' in Paul should be mentioned here as well. Paul's letters clearly express a degree of continuity with what preceded him. It is better not to use the term 'Christianity' for Paul and his movement, simply because the term had not yet been coined in his day. Instead, the term 'Christ movement' shall be used to address that Jewish movement that eventually turned into what we now call 'Christianity'.

For Paul, the Christ movement equalled 'Israel'. The terms he uses to describe his movement's identity are taken from the tradition of Israel and the most prominent of these terms

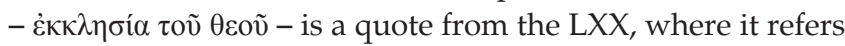
to the qe'hal Yisrael, the gathering of Israel. ${ }^{7}$ Much has been written about this equation, and it is better not to add much

5.The extent to which ancient personality was formed in a group culture is expressed most clearly, perhaps, by Malina and Neyrey (1996:1-18).

6.This point is discussed by Dunn (1996:1-26). Dunn distinguishes three levels in Paul, and considers the 'theology' of Paul present in the interaction between the three levels: inherited convictions, biographical elements, and the interaction with everyday life.

7.See Lietaert Peerbolte (2003a:213-221). See also Berger (1976), and Merklein (1979). Parallel usage of the Hebrew term qe'hal is attested in for example, 1QM 4:10 and 1QSa 2:4. 
to that in the present context. As a result of this particular

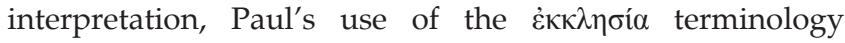
implicitly identifies this particular movement with what he saw as the loyal remainder of Israel. ${ }^{8}$

The study of Paul as a Jewish author has received a new impetus since the rise of the so-called 'new perspective' on Paul. The one thing that has become thoroughly clear is that Paul was and remained a Jewish author. ${ }^{9}$ The question whether or not he thought that Jewish followers of Jesus Christ were to uphold the Mosaic Law need not be considered for the present purpose. What is important here, is that Paul saw the movement started by the Christ event as a new form of Israel. Paul looked at newcomers to this specific, Messiahcentred type of Israel, both Jewish and pagan, as members of the true Israel who had to adhere to certain moral rules. This is maybe the most important point of the present contribution: that Paul's theology thoroughly influenced his perception of morality. Paul's ethics are deeply rooted in his theology.

The remainder of this contribution will focus on a number of issues to substantiate this point. In three sections, the way Paul uses theological concepts to underline the group identity of the Christ movement will be looked into. The next section of this article focuses on how Paul pictures the social reality of his converts by fencing off their present from their past. The third part deals with Paul's description of the boundaries with the outside world. And the subsequent section describes how Paul's moral admonitions reflect traditional Jewish concepts such as holiness and purification.

\section{Fencing off the past}

The fencing off of social groups through letter writing should be seen as part of a mechanism of identity formation. In both cases, what Paul does is to rhetorically create a boundary between the in-group and the outside group in what Esler calls a 'process of inter-group comparison' (Esler 1998:29-57). Both movements attempt to create a mental boundary between the Christ group and the outside world.

One well known passage, in which Paul explicitly creates such a boundary - in this case between the present and the past - is 1 Thessalonians 1:9-10. Here, Paul speaks about the way in which the Thessalonians have 'turned away toward God from the idols, to serve the living and true God and

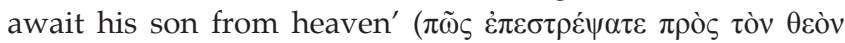

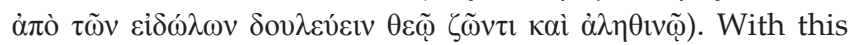
phrase, Paul clearly addresses pagan followers of Christ, and indicates that they have made a decisive shift. ${ }^{10}$ The past

8.This is particularly clear from Paul's argument in Romans $9-11$

9.See for example, Boyarin (1994), Eisenbaum (2009), Gager (2000), Nanos (1996, 2002).

10.Bruce (1982:170) mentions the fact that $\dot{\varepsilon} \pi 1 \sigma \tau \rho \dot{\varepsilon} \varphi \omega$ is 'common in Acts in the sense of evangelical conversion', but not in Paul. He 'uses it once only of turning to the of evangelical conversion', but not in Paul. He 'uses it once only of turning to Lord (2 Cor 3:16) in a quotation from the Old Testament (OT) and once of turnin (that 'Paul may well have been a jewish missionary before he became an apostle of Christ. As result, Wannamaker sees the phrase used in 1:10 as Jewish missionary language (Wannamaker 1990:85). For an argument against the existence of the Jewish proselytising mission in the first century, see Lietaert Peerbolte (2003a:55-79). is gone and the present is portrayed as a turning toward the truth. ${ }^{11}$

The language in which Paul describes this turning away from the idols is influenced by the traditional Jewish rhetoric against idolatry, and clearly labels the transition of pagan followers of Christ from their polytheistic context to the monotheism of Israel (1 Th 1:9-10). ${ }^{12}$ This transition is seen as a major shift in their life, a break with the past.

Now it might be tempting to think that Paul saw this shift, this break as something that concerned the pagan followers of Christ only. That this is not the case is indicated by Paul's argument in Galatians. There, he addresses a group of primarily pagan addressees, but includes Jews in his argument. He stresses the fact that the present is the era of faith, whereas the past was ruled by the Law. The rhetoric of Galatians 3:23-29 implies both a continuity and a break with the past, for pagan, but also for Jewish followers of Christ. ${ }^{13}$ That Jewish followers are included in the argument

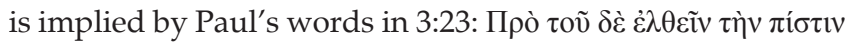

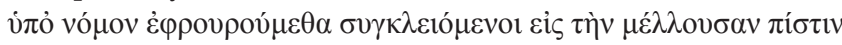
$\dot{\alpha} \pi о \kappa \alpha \lambda \nu \varphi \theta \tilde{\eta} v \alpha$. The first person plural 'we were kept under the law' does not refer to pagans, but to Jews. ${ }^{14}$ Paul links the concept of the Law as pedagogue to the metaphor of childhood. By using this specific metaphor, Paul indicates that the transition from Law to Faith was a transition into adulthood, and for Jewish followers of Christ this means that there is both continuity and a shift.

In the same letter to the Galatians, Paul defines the wish to keep the Mosaic Law as a return to the weak and poor powers $(4: 8-11) .{ }^{15}$ An interesting detail is that in 1 Thessalonians 1:10 Paul uses the combination $\dot{\varepsilon} \pi \iota \tau \rho \varepsilon \dot{\varphi} \varphi \omega \pi \rho$ ó $\varsigma$ for the converts' turn away from the idols, toward God, and here he expresses

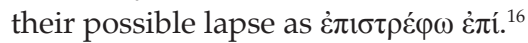

In what might be rhetorically the boldest, and shortest expression of the break between past and present, in Romans 3:21, Paul expresses the same combination of continuity and

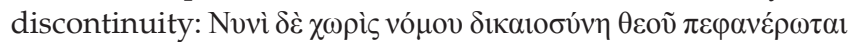

11.Nanos (2002:244-249), considers this break with the past as the beginning of a process of becoming Jewish: 'The liminal stage characterizes the time of transition, when one is no longer a pagan but not yet Jewish, not having completed the rituall process, and in most cases, the training that would be expected to occupy the process, and in most cases, the training that would be expected to occupy the
proselyte candidate in the meantime' (p. 245). In this approach, the turning away proselyte candidate in the meantime' (p. 245). In this approach, the turning away
from the idols as depicted in 1 Thessalonians 1:9-10 would be a description of the first step of the process of becoming a Jewish proselyte. It is, however, doubtful that this is what Paul had in mind.

12. Holtz (1986:54-62), is rightly sceptical about the possibility of reconstructing an early Christian kerygma on the basis of 1:9-10. He does give material that indicates the Jewish character of the expressions used (esp. pp. 57-58).

13.In H.D. Betz's terms: 'It is clear (...) that two mythico-historical periods are to be distinguished: the period of the Law and the period of the faith' (Betz 1979:175-176). The rupture described by Paul in Galatians 2:23-25 is summarised by Longenecker: ' (...) with the coming of the Christian gospel (...) as effected by Christ, the law no longer has validity as a $\pi \alpha i \delta \alpha \gamma \omega \gamma$ ó $\zeta$ regulating the life of faith (Longenecker 1990:149).

14.See for example, Betz (1979:176).

15.See De Boer (2011:270-277), especially page 275: 'Paul therefore makes clear that for the Galatians to turn to the observance of the law is effectively to return (...) to the veneration of the stoicheia and thus of the gods they had previously worshiped (...)

16.See also 2 Corinthians 3:16; Holtz (1986:59). De Boer (2011:275), interprets $\dot{\varepsilon} \pi 1 \sigma \tau \rho \dot{\varepsilon} \varphi \omega$ in this context as 'reconvert'. 


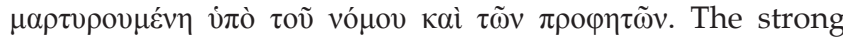
emphasis on 'now' or voví implies a break with the past, and it is the past that Paul has pictured in the preceding sections. ${ }^{17}$ After his general introduction in Romans 1:18 Paul continues with a description of the reason why human beings in general - read: pagans! - are the subject of God's wrath. This description continues from 2:17 with the well known indictment of 'you, who call yourself a Jew, have faith in the Law.' After his description of the general state of humankind (Greek and Jew), the turn in 3:21 (vvví!) stresses a huge break with the past. The 'now' indicates a new beginning, a major change brought about by God himself. Here, as elsewhere in Paul's letters, ${ }^{18}$ it is evident that the advent of Christ has brought about a decisive change in history, which is reason for Paul to fence off the present from the past. The boundary Paul creates by this eschatological interpretation of the Christ event is thus not only a sociological and biographical boundary. For Paul, this boundary is rooted in the cosmos and in history. He is convinced it is God himself who has created this boundary. According to Paul, the Christ event meant the arrival of something entirely new. He can even speak of the advent of the 'new creation' (Gl 6:16; 2 Cor 5:17). ${ }^{19}$ Becoming a member of this movement, becoming a follower of Christ, thus meant a break with the past, not just for pagans, but also for Jews. At the same time, this specific community, governed by the Spirit of God, was seen as the 'inside' over against the 'outside world'. Paul fences off this community not just from the past, but also from others in the present. It is with this second boundary that the next section is concerned.

\section{Fencing off the present}

The identity of the Christ movement as the 'elect', the 'chosen ones in Christ' for Paul automatically fences off this group from the outside world. ${ }^{20}$ There are several passages in Paul's letters where he describes the relation of the Christ movement to the outside world. Time and again he does so in terms that presuppose a closed community that sees itself as set apart from the rest of the world.

In Paul's treatment of the fate of the dead, in 1 Thessalonians, he needs only a few words to indicate the difference between the followers of Christ and the rest of the world. For Paul,

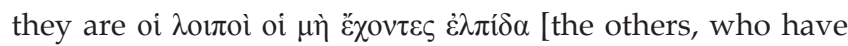
no hope]. Paul sees the followers of Christ as the ones who will be saved (1 Th 1:10), and this is the decisive distinction between them and the rest of the world. In his admonition in 5:1-10, Paul describes the boundary between the two groups

17.See Cranfield (1975:201): 'In view of the presence of $\pi \varepsilon \varphi \alpha v \varepsilon \omega \tau \alpha$ the contention of some commentators that voví has a purely logical force here must surely be rejected, and its temporal significance firmly maintained.' Also, though slightly different, Michel (1978:147) and Lohse (2003:129).

18.The clearest expression of this change is found in Galatians $4: 4$, where Pau

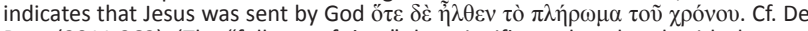
Boer (2011.262): "The "fullness of time" thus signifies a clean break with the past Boer (2011:262): 'The "fullness of time" thus signifies a clean break with the past end of "the present evil age" (1:4) and the beginning of the "new creation" (6:15).'

19.On the concept of 'new creation', see De Boer (2011:402-403).

20.See Romans 1:6-7; 8:28; 1 Corinthians 1:2, 24. in traditional moral terms: the insiders are ruled by light and day, outsiders by darkness and night. ${ }^{21}$

The idea that the followers of Christ form a confined community in which they should take care of themselves and each other is substantiated in a number of other passages. In a topos known from Hellenstic philosophy, Paul regularly advises his followers to imitate him as he imitates Christ. ${ }^{22}$ But more importantly, Paul underlines the chasm between the Christ community and the outside world. In his discussion of how to handle conflicts, Paul admonishes the Corinthians to solve their problems within their community, instead of taking other followers of Christ to a Gentile court. The passage in which Paul does so (1 Cor 6:1-6) is so important to the present subject that a brief discussion is warranted here.

Whatever the exact nature of the conflict Paul aims at in 1 Corinthians 6:1, it is clear that he has received word from the Corinthian envoys that there were those within the Corinthian congregation who wanted to solve the problems they had with each other by taking the other person to court. $^{23}$ By Paul's somewhat irritated way of introducing this problem, he points out that this is not the way he wants

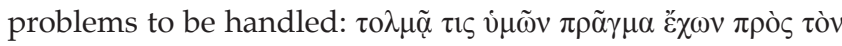

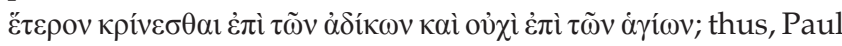
implicitly makes the point that he identifies the members of the Christ community as the ö $\gamma 10$ and the outsiders as $\dot{\alpha} \delta$ í $^{2}{ }^{24}$ The way in which Paul gives the reason for his indignation

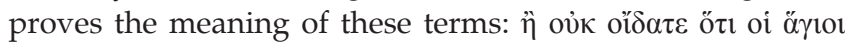

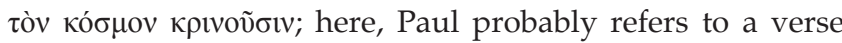
in Daniel 7:22, where it is stated that the 'ancient of days' renders the judgement of the earth to 'the holy ones of the Most High' ${ }^{25}$ It is most likely that these 'holy ones' stand for the people of Israel in their heavenly glory. ${ }^{26}$ If this is correct, Paul applies this specific eschatological designation to the members of the Christ movement. For him, they equal the eschatological Israel, and he applies the prophecy of Daniel to them in order to substantiate his point that they should not be judged by outsiders. Apparently, Paul sees the followers of Christ as the God-ordained, eschatological Israel. It is for this reason that he can say in verse 3 that the 'holy ones' will even pass judgement on the angels. ${ }^{27}$

Perhaps it is this view of the followers of Christ as the heavenly, eschatological Israel, that enables Paul to speak

21.'Light' symbolises God's presence (e.g. Mt 17:2; Lk 16:8; Jn 12:35; Ac 9:3; 12:7; 1 Jn 2:7), whereas 'darkness' is a symbol for a life without God (see e.g. Mt 8:12; 22:13 25:30; Lk 1:79; Jn 3:19; Rm 1:21; Eph 5:11; 6:12).

22.See for example, 1 Thessalonians 1:6; 1 Corinthians 4:16; $11: 1$ [!]; Philippians 3:17 4:9; cf. Malherbe (1989:67-77). The classic study on Paul' indebtedness to (Stoic) philosophers is Engberg-Pedersen (2000).

23.For a more detailed analysis, see Fee (1987:228-248).

24.Fee (1987:234): 'So inclusive will be our participation in God's eschatological judgment that not only the world but even the angels will be judged by the newly formed eschatological people of God.' The 'our' in this quote is remarkable, since it betrays a lack of hermeneutical distance. In scholarly exegesis it is better not to equate the ancient audience with modern recipients.

25.The MT Daniel 7:22 reads החסינו קדישין and LXX simply oi ä ölot.

26.Pace for example, Collins (1993:312-318).

27.For 'holiness' as an epithet of the believers, see Balz \& Schneider (1990), s.v. $\tilde{\alpha} \gamma \operatorname{los} 5$. 
of their polity as a heavenly one. In Philippians 3:20 Paul famously argues that their citizenship is of heaven: $\dot{\eta} \mu \tilde{\omega} v$

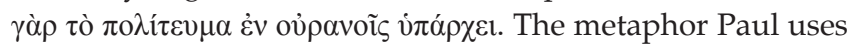
here indicates that the Christ community is ruled by heaven, and that no earthly ruler can rise above the authority that the followers of Christ submit to. There is a striking semantic correspondence of Philippians 3:20 to 1:27: the noun $\pi \mathrm{o} \lambda i \tau \varepsilon v \mu \alpha$ in 3:20 is a cognate to the verb $\pi \mathrm{o} \lambda \imath \varepsilon \varepsilon v \varepsilon \sigma \theta \alpha \mathrm{l}$, which Paul uses in 1:27 to describe the conduct of the followers of Christ as 'worthy of the gospel'. This striking semantic correspondence indicates that for Paul the heavenly origin of the identity of the followers of Christ should lead to a certain type of behaviour.

\section{Noblesse Oblige: An insider's perspective}

The matter that Paul discusses in 1 Corinthians 6:1-6 can be easily summarised as noblesse oblige. The status of the followers of Christ was considered so high that Paul would not allow any outsider to pass judgement on them. We have already seen how Paul creates a mental boundary for the Christ movement by stressing the gap between the present and the past. The present is defined by the 'already' and 'not yet' of the eschatological intervention of God in history. The gap is created by a theological interpretation of the place of the Christ group in history: the advent of Christ has led to a rupture with the past, opening up the future to the present in a way that allows the believers to see their own situation as a break with the past. At the same time, Paul stresses the boundaries between the followers of Christ on the one hand and the rest of the world on the other. In a number of passages in the Pauline epistles Paul appears to connect these two boundaries - the one in the past and the one in the present - to a type of behaviour, a moral conduct that he considers correct for followers of Christ.

From the abundance of evidence Paul presents us with in his undisputed letters, a few examples will be taken to point out how his admonitions focus on a morality that should surpass that of the outside world. For Paul, this surpassing morality is linked to his interpretation of the identity of the Christ movement. As said above, Paul sees this particular movement as the true Israel, the loyal remnant into which Gentiles are admitted thanks to Christ. As a result, Paul's focus is both on upholding the highest standards - noblesse oblige - and on stressing the difference with the outside world.

In 1 Thessalonians 4:3-7 Paul emphasises the fact that God

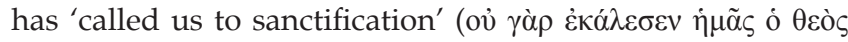

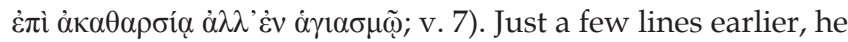
has argued that the followers of Christ should not live 'like

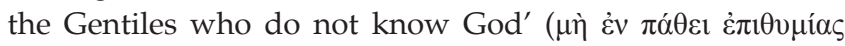

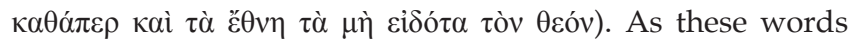
indicate, Paul saw the pagan followers of Christ as full members of Israel. ${ }^{28}$ According to him, what set them and

28. Holtz (1986:160-161), does mention the fact that this characterisation labels the outside world as 'pagans', but overlooks the implicit identification of the inside world as 'Israel'.
Jewish followers of Christ apart from outsiders, was that they had been 'called' by God into the 'new creation'. The use of $\kappa \alpha \lambda \varepsilon \dot{\omega} \omega$ in this context is of great importance. The idea is that God is the one who starts the action. ${ }^{29}$ In Paul's thought, it is God who takes the initiative to invite the believers into the community of Christ. It is all the more telling that Paul uses traditional Jewish values like 'sanctification' and 'purity' to instruct the believers with regard to the right conduct.

In the first letter to the Corinthians a number of passages deserve to be studied here. For reasons of time and space, but a few examples will need to suffice. The first of these is the remark Paul makes in 3:16-17. There, Paul argues that the Christ community should be holy, since its members 'are' (!)

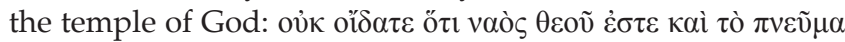

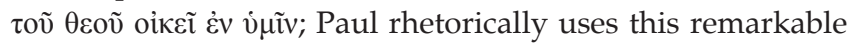
identification of the Christ community of Corinth as 'God's temple' to formulate his admonition that the members of

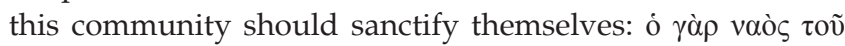

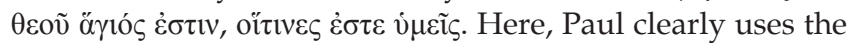
theological identity of the Christ community as a rhetorical argument to stress the need for sanctification. Could it be that this theme is so prominent in 1 Corinthians because of the especially libertine character of this city? Was it by

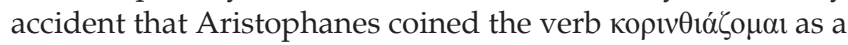
euphemism for sexual misconduct? ${ }^{30}$

One of the most vehement attacks by Paul on sexual misconduct is found in 1 Corinthians 5 . Here, too, Paul argues in a way that betrays his view of the Christ community as 'Israel', since he expresses his indignation by referring to the outside world as the $\tilde{\varepsilon} \theta \mathrm{v} \eta$. Thus, he implicitly labels the inside

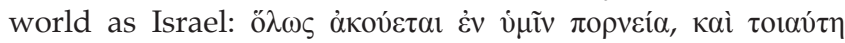

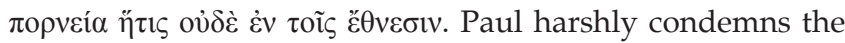
person who is apparently sleeping with his stepmother. ${ }^{31}$ In his view, this man should be expelled: the two remarks Paul makes in his argument are important to capture. The formula Paul uses in verse 4 most likely refers to a double authority: the name of the Lord Jesus and Paul's own authority, derived from the 'power of the Lord'. On behalf of these two authorities, the congregation should cast the man out to 'hand him over to Satan, for his flesh to be destroyed'

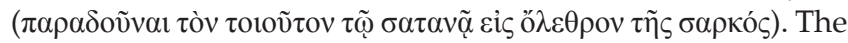
question of what exactly Paul has in mind here does not need to be discussed at this moment. What is important for the present argument is that Paul equates the outside world with the dominion of Satan. The outside world is evil, ruled by

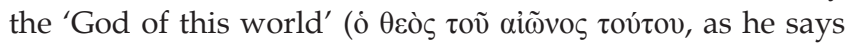
in 2 Cor 4:4). The inside world is God's world, the world of Christ, of the Spirit. In the description of this specific case morality and the boundary with the outside world seem to almost coincide. This is further underlined by Paul's final

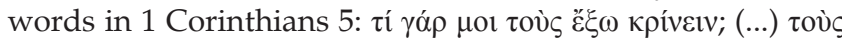

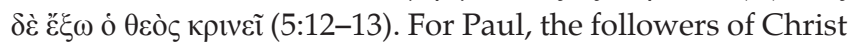
have to pass judgement upon themselves, since the rest of the world will be judged by God.

29.See for example, Romans 4:17; 9:25; Galatians $1: 6,15 ; 5: 8$; 1 Thessalonians $2: 12$ $5: 24$

30.Aristophanes, Fragm. 354

31.For this pericope, see Fee (1987:198-213). 
The same paradoxical tension between the inside and the outside world is found in the discussion of sacrificial meat in 1 Corinthians 8 . One important point made in this chapter is this: whilst Paul admits to the existence of many gods and lords, he stresses that 'for us there is only one God and one Lord.' Here too, Paul's idea seems to be that the followers of Christ are under the dominion of God and Christ, ruled by the Spirit. Paul thus turns a theological boundary into a sociological boundary by using it as a moral boundary.

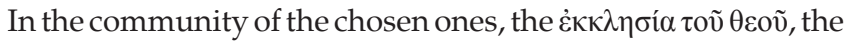
fundamental principle of morality in general seems to have been the holiness code of Leviticus 11:44-45: 'you should be holy, for I, the LORD, am holy.'32 This is perhaps indicative of the paradox posed by Paul: whilst he is arguing that at least the Gentiles should not be forced to keep the Mosaic Law, and he apparently regards the literal interpretation of that Law by Jewish followers of Christ as no longer necessary, he seems to found his ethical approach toward the new movement on that same Torah. Further research at this point is needed, but for now it may suffice to state that Paul seems to implicitly apply the ideals of the holiness code to the Christ movement. $^{33}$

\section{Mission and the narrative substructure of Paul's ideas}

Up to this point, the focus has been on the boundaries that Paul establishes between present and past on the one hand, and the inside and outside world on the other hand. Paul's stress on ethical demands has been discussed as a sign of belonging to the Israel in Christ, the group of the chosen ones, who are called by God. In all this, the main emphasis has been on Paul's idea of the Christ movement as the 'true Israel', and the effect of this on the ethical standards that he thought should be upheld within that community. In this final section it is time to ask: how should we identify the narrative substructure of Paul's ideas on mission, on the Christ movement as 'true Israel', and on the corresponding ethical demands?

The first step to uncovering the narrative substructure of Paul's discourse on mission is to realise that he considered himself 'sent' by God. The term he uses for himself is $\dot{\alpha} \pi$ ó $\sigma \tau{ }_{0} \lambda \mathrm{o}_{,},{ }^{34}$ a noun that is so often translated as 'apostle' that one would almost forget that its meaning is primarily 'envoy'. Paul considered himself an 'envoy of the Anointed One', one who was sent to proclaim the good news of the Christ event. The verb Paul uses for the proclamation of the

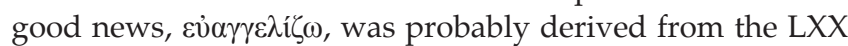
of Isaiah. ${ }^{35}$ The passage in which Paul speaks perhaps most clearly of this task, is Galatians 1:15-16. ${ }^{36}$ An important detail in the vocabulary Paul uses here is his choice of the verbs. God is the one who has 'set Paul apart' from his mother's

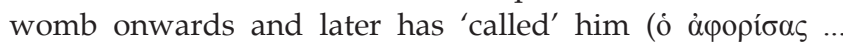

32.See also Leviticus 19:2; 20:7, 26.

33.See Eisenbaum (2009).

34.Romans $1: 1 ; 11: 13 ; 1$ Corinthians $1: 1 ; 4: 9 ; 9: 1-2,5 ; 15: 9 ; 2$ Corinthians $1: 1 ; 12: 12$ Galatians 1:1, 17; 1 Thessalonians 2:7.

35.See LXX Isaiah 40:9; 52:7; 60:6; 61:1.

36.Lietaert Peerbolte (2003a:167-170).

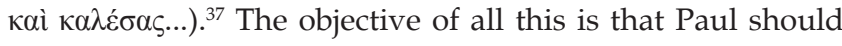

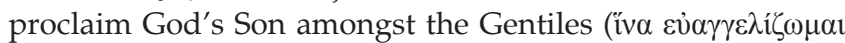

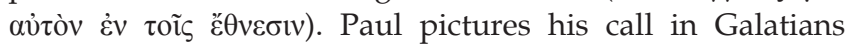
1:15-16 in terms that closely resemble the call of Jeremiah, but also that of Isaiah. Thus, he consciously positions himself within the prophetic tradition. As the prophets were 'sent' by YHWH, Paul considers himself 'sent' by the same God who has now revealed himself through his Son, Jesus Christ.

It is here that Paul appears to position not only himself in the tradition of the prophets, but also Jesus Christ. In the same letter to the Galatians, Paul states that God has 'sent' his son:

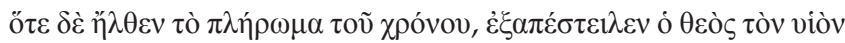

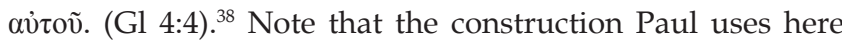
runs more or less parallel to his description of his own call in 1:15-16: first a temporal clause introduced by ö $\tau \varepsilon$, followed by the decisive act by God, and next the intended result of that act in a final clause with ivo. Paul interprets his own task through the discourse of 'being sent': much in the same way as Christ has been sent by God, Paul considers himself as sent to proclaim Christ. ${ }^{39}$

The motif of 'being sent' is probably derived from the prophetic tradition of Israel as well. ${ }^{40}$ In LXX Isaiah 6:8 Isaiah

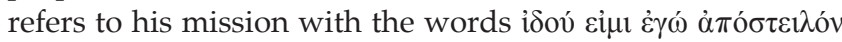
$\mu \varepsilon$. The 'sending' of the prophets and envoys by $\mathrm{YHWH}$ to Israel is found in numerous passages throughout the Old Testament. ${ }^{41}$ Paul thus interprets both his own mission and that of Jesus as initiated by God, and connected to the tradition of the prophets of old. Paul considered himself 'sent'; he was 'on a mission' to help proclaim the gospel and build Israel the way he saw it.

Many studies have been dedicated to the influence of Isaiah, and especially deutero- and trito-Isaiah, on Paul. ${ }^{42}$ This is not a coincidence for it is here that we find the idea that the Gentiles will flock to Zion in the last days. ${ }^{43}$ It looks as though Paul thought of the Christ movement as the fulfilment of this particular prophecy, albeit in another form than the one described by Isaiah. It is this vision that Paul describes in Romans 15 when he refers to Isaiah and describes how the Gentiles bring their offerings to Zion as a metaphor for the inclusion of non-Jewish followers of Christ into the eschatological Israel. ${ }^{44}$

The observation that Paul interpreted both himself and his mission from a prophetic and eschatological perspective raises the question: where did it start? In Paul's case

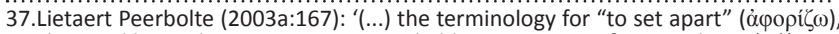
also used by Paul in Romans 1:1, is probably reminiscent of Jeremiah 1:5 (...)'.

38.Galatians 4:6 is the only other verse in the Pauline epistles where Paul uses this particular verb for Christ's mission.

39.In 1 Corinthians 1:17 Paul states that he sees Christ as the one who has sent him. 40.Lietaert Peerbolte (2003a:177-201).

41.To mention but a few examples: Isaiah 48:16; 61:1; Jeremiah 14:14-15; 19:14 42:15.

42.See especially Wagner (2002).

43. Especially Isaiah 66:18-21. This particular passage caused Riesner (1994:213-225) to suppose that Paul saw his own task as a fulfilment of this particular prophecy. See also Gilbert (2010:672).

44.Lietaert Peerbolte (2003b). 
theology and biography are so closely intertwined that it is difficult to separate the two. It seems that Paul's conversion experience resulted in his conviction that God had touched him, had revealed Christ to him. ${ }^{45}$ This particular experience changed his life. Subsequently, it seems, the experience of the community of believers in Antioch, that consisted of Greeks and Jews, taught him that God had chosen to include the Gentiles in his new covenant. ${ }^{46}$ And the rest, so to speak, is history.

\section{Conclusion}

Much more can, and should, be said about the topics dealt with in this contribution. Still, the main points that were argued above can be summarised as follows:

1. Paul emphasises clear boundaries between the Christ community and the outside world, both with regard to the present and with regard to the past. The converts who have joined the Christ movement have broken with their past, and the group they live in clearly separates itself from the surrounding world. Interestingly enough, those two characteristics are often found in modern groups that are labelled as 'sectarian'.

2. In a number of passages, Paul interprets the past state of the followers of Christ as one of submission. They served the idols instead of the living God; they submitted themselves to the powers of the cosmos. Now, Paul considers them liberated by Christ.

3. For Paul, the movement of followers of Christ - Jew and Greek alike - is the eschatological Israel, with which God has made a new covenant. In his eyes, this particular movement reflects the true, eschatological Israel and is called to that state by God. Paul's mission is founded on this idea, and for him the new Israel of Jew and Greek together is proof that the prophecies of Isaiah were being fulfilled in his day: the Gentiles were turning toward Zion.

4. This particular definition of the Christ movement in terms of Israel automatically ushers in a morality that is closely linked to that of the Law. The ethos Paul demands of the followers of Christ comes close to the holiness code of Leviticus. He argues that they should live their lives according to the will of God, and should sanctify themselves. Paul uses the discourses of sanctification and purification, but intriguingly does not want pagan followers of Jesus to keep the Mosaic commandments. Apparently, morality for Paul did not coincide with the Mosaic Law. This is a theme that moves away from the scope of the present contribution, though it is certainly worthy of further consideration.

\section{Acknowledgements Competing interests}

The author declares that he has no financial or personal relationship(s) which may have inappropriately influenced him in writing this article.

45.On the terminology of 'conversion' versus 'call', see Segal (1990), passim. Segal correctly argues that 'conversion' is the etic term, whereas 'call' is the emic word correctly argues that
Paul himself used.

46. A subsequent experience that influenced Paul to a similar degree was the incident in Antioch. See for example, Dunn (1983).

\section{References}

Balz, H. \& Schneider, G., 1990, Exegetical Dictionary to the New Testament, Eerdmans, Grand Rapids.

Berger, K., 1976, 'Volksversammlung und Gemeinde Gottes: zu den Anfängen der christlichen Verwendung von "Ekklesia", Zeitschrift für Theologie und Kirche 73, 167-207.

Betz, H.D., 1979, Galatians: A Commentary on Paul's Letter to the Churches in Galatia, Fortress Press, Philadelphia. (Hermeneia).

Boyarin, D., 1994, A Radical Jew: Paul and the Politics of Identity, University of California Press, Berkeley.

Bruce, F.F., 1982, 1 and 2 Thessalonians, Waco, Word Books. (Word Biblical Commentary).

Collins, J.J., 1993, Daniel: A Commentary on the Book of Daniel, Fortress Press, Minneapolis. (Hermeneia).

Cranfield, C.E.B., 1975, The Epistle to the Romans, vol. 1, T\&T Clark, Edinburgh (International Critical Commentary).

De Boer, M.C., 2011, Galatians: A Commentary, Westminster John Knox Press, Louisville. (The New Testament Library).

Dunn, J.D.G., 1983, 'The Incident at Antioch (Gal 2:11-18)', Journal for the Study of the New Testament 18, 3-57. http://dx.doi.org/10.1177/0142064X8300501801

Dunn, J.D.G., 1996, The Theology of Paul the Apostle, T\&T Clark, Edinburgh.

Eisenbaum, P., 2009, Paul was Not A Christian, Harper Collins, San Francisco.

Engberg-Pedersen, T., 2000, Paul and the Stoics, Westminster John Knox Press, Louisville.

Esler, P., 1998, Galatians, Routledge, London.

Fee, G.D., 1987, The First Epistle to the Corinthians, Eerdmans, Grand Rapids. (New International Commentary).

Gager, J.G., 2000, Reinventing Paul, Oxford University Press, New York.

Gilbert, G. 2010, 'Gentiles, Jewish Attitudes toward', in J.J. Collins \& D.C. Harlow (eds.) The Eerdmans Dictionary of Early Judaism, pp. 670-673, Eerdmans, Grand Rapids/ Cambridge.

Holtz, T., 1986, Der erste Brief an die Thessalonicher, Benziger Verlag, Zürich/ Neukirchener Verlag, Neukirchen-Vluyn. (Evangelisch-Katholischer Kommentar zum Neuen Testament).

Lietaert Peerbolte, L.J., 2003a, Paul the Missionary, Peeters, Leuven. (Contributions to Biblical Exegesis and Theology 34).

Lietaert Peerbolte, L.J., 2003b, 'Romans 15:14-29 and Paul's Missionary Agenda', in P.W. van der Horst, M.J.J. Menken, G.C.M. van Oyen \& J.F.M. Smit (eds.), Persuasion and Dissuasion in Early Christianity, Ancient Judaism, and Hellenism, pp. 143-159, Peeters, Leuven. (Contributions to Biblical Exegesis and Theology 33).

Lietaert Peerbolte, L.J., 2010, Paulus en de rest: Van farizeeër tot profeet van Jezus, Meinema, Zoetermeer.

Lohse, E., 2003, Der Brief an die Römer, VandenHoeck\&Ruprecht, Göttingen. (Kritischexegetischer Kommentar zum Neuen Testament).

Longenecker, R., 1990, Galatians, Word Books, Dallas. (Word Biblical Commentary).

Malherbe, A., 1986, Moral Exhortation: A Greco-Roman Sourcebook, Westminster Press, Philadelphia.

Malherbe, A., 1987, Paul and the Thessalonians: A Philosophic Tradition of Pastoral Care, Fortress Press, Philadelphia.

Malherbe, A., 1989, Paul and the Popular Philosophers, Fortress Press, Minneapolis.

Malina, B.J. \& Neyrey, J.H., 1996, Portraits of Paul: An Archaeology of Ancient Personality, Westminster John Knox Press, Louisville.

Meeks, W.A., 1993, The Origins of Christian Morality. The First Two Centuries, Yale University Press, New Haven/London.

Merklein, H., 1979, 'Die Ekklesia Gottes: Der Kirchenbegriff bei Paulus und in Jerusalem', Biblische Zeitschrift 23, 48-70.

Michel, O., 1978, Der Brief an die Römer, 14th edn., VandenHoeck\&Ruprecht, Göttingen. (Kritisch-exegetischer Kommentar zum Neuen Testament).

Nanos, M., 1996, The Mystery of Romans: The Jewish Context of Paul's Letter, Augsburg Fortress, Minneapolis.

Nanos, M., 2002, The Irony of Galatians: Paul's Letter in First-Century Context, Augsburg Fortress, Minneapolis.

Riesner, R., 1994, Die Frühzeit des Apostels Paulus. Studien zur Chronologie, Missionsstrategie und Theologie, Mohr Siebeck, Tübingen. (Wissenschaftliche Untersuchungen zum Neuen Testament 71).

Segal, A.F., 1990, Paul the Convert: The Apostolate and Apostasy of Saul the Pharisee, Yale University Press, New Haven/London.

Van der Watt, J.G. (ed.), 2006, Identity, Ethics, and Ethos in the New Testament, De Gruyter, Berlin. (Beihefte zur Zeitschrift für die neutestamentliche Wissenschaft und die Kunde der älteren Kirche 141).

Wagner, J.R., 2002, Heralds of the Good News: Isaiah and Paul 'in Concert' in the Letter to the Romans, Brill, Leiden. (Supplements to Novum Testamentum 101).

Wannamaker, C.A., 1990, The Epistles to the Thessalonians: A Commentary on the Greek Text, Exeter, Grand Rapids/Eerdmans, Paternoster. 